\title{
Extracts of White and Red Grape Skin and Rosehip Fruit: Phenolic Compounds and their Antioxidative Activity
}

\author{
Maša Knez Hrnčič, ${ }^{1, \star}$ Darija Cör, ${ }^{1}$ Petra Kotnik ${ }^{1,2}$ and Željko Knez ${ }^{1,2}$ \\ ${ }^{1}$ University of Maribor, Faculty of Chemistry and Chemical Engineering, Smetanova 17, SI-2000 Maribor, Slovenia, \\ ${ }^{2}$ University of Maribor, Faculty of Medicine, Taborska ulica 8, SI-2000 Maribor, Slovenia, \\ *Corresponding author: E-mail: masa.knez@um.si \\ Phone: +3862 2294477, fax:+38622527774
}

Received: 05-09-2019

\begin{abstract}
The current work concerns solid liquid extraction from red and white grapes skin and the rosehip (Rosa canina) to obtain extracts with a high phenolic content. Extracts have been acquired using conventional extraction techniques and extraction with supercritical fluids (SCFs). The effect of extraction method and experimental parameters (time, pressure, temperature and solvent mixture) mostly believed to affect the extraction process was undertaken. The quantitative parameters studied are: total phenolic compounds, proanthocyanin content, and the phenolic constituent profile. The qualitative parameter analyzed is antioxidant capacity. The results demonstrate that the contents of the major constituents significantly varied among the different types of materials. The highest content of total phenolics was determined in the extract from the white grape skin, macerated with $\mathrm{MeOH}(26.7 \mathrm{mg} \mathrm{GA} / \mathrm{g}$ extract), and similar, $25.6 \mathrm{mg} \mathrm{GA} / \mathrm{g}$ extract in the $\mathrm{MeOH}$ extract attained by Soxhlet. Ellagic acid $(0.650 \mathrm{mg} / 100 \mathrm{~g}$ extract), catechin $(0.164 \mathrm{mg} / 100 \mathrm{~g}$ extract), gallic acid $(0.133 \mathrm{mg} / 100 \mathrm{~g}$ extract $)$ as well as caffeic acid $(0.038 \mathrm{mg} / 100 \mathrm{~g}$ extract $)$ are the major compounds present in the rosehip extracts attained by maceration using $\mathrm{MeOH}$ as solvent. The presence of epictechin, hesperidin/neohesperidin, rutin, and chlorogenic acid was also confirmed. Aspects of each type of processing were correlated with the chemistry of the material. The obtained extracts could be used as natural bioactive compounds in several industrial applications.
\end{abstract}

Keywords: Phenolic compounds; Conventional extraction; Supercritical fluid extraction; LC-MS; DPPH.

\section{Introduction}

Increasing pressure on natural resources and the problems caused by unhealthy eating habits have brought along an enlarged incidence of different types of cancer. Besides, the worldwide population is aging and countries are facing ongoing challenges in caring for their elderly. Consequently, the demand for different types of high quality products is increasing. Substantial investigation has been concentrated on fruits and crops containing antioxidant bioactive compounds. A bioactive compound is known as a substance that beneficially influences the health of living organisms. These extra nutritional constituents are present in both plant and animal products, and typically occur in low quantities in foods. High ingestion of fruits has consequently been associated with low incidence of chronic-degenerative diseases, probably due to the presence of bioactive compounds, considered to enhance or boost the immune system. ${ }^{1}$ Here, extraction is an important process to isolate the bioactive compounds. Biological activities of the extract highly depends on the extraction procedure and this releases a gateway for selection of appropriate extraction methods. A great deal of interest has been devoted to the extraction of active components from natural sources, aiming at satisfying the increasing request of natural products not only for therapeutic use but also as preventing and protecting agents. ${ }^{2}$ Among the large number of active substances in the focus, polyphenols have received particular attention in the last decade. ${ }^{3}$ The identification and development of phenolic compounds or extracts from different plants has become a major area of food, health- and medical-related research. ${ }^{4}$ Divided into two major groups (nonflavonoid and flavonoids), phenolic compounds show antioxidant and radical scavenging activities possibly responsible for many health benefit effects ${ }^{5}$ and for the yellow, orange and red pigments in a large variety of plants and animal kingdoms. ${ }^{6}$ Extracts containing these natural ingredients are incorporated into 
different food, therapeutic and cosmetic products. Nutritional composition, colour and antioxidant activity of such products depends on the total composition of the extract. The development of such novel functional products emphasizes the bioactive and preservation potential of phenolic compounds. Most of the compounds were extracted using Soxhlet and conventional solvent extraction methods. ${ }^{7}$ However, conventional solvent extraction has certain disadvantages such as application of large amount of solvents, long extraction times, and the presence of toxic organic solvents in the final products. ${ }^{8}$ Those can lead to deterioration of the quality of the extracts and can cause thoughtful health difficulties. ${ }^{9}$ Indeed, conventional techniques have been widely accepted, mainly because of the ease of procedure, effectiveness, and widespread applicability. ${ }^{10,11}$

Processes based on SCFs are an environment-friendly alternative to traditional solvent extraction techniques. ${ }^{12}$ Supercritical carbon dioxide $\left(\mathrm{SC} \mathrm{CO}_{2}\right)$ is the most prominent amongst various solvents used in this method because of the low critical temperature $\left(31.18^{\circ} \mathrm{C}\right)$ and pressure $(7.4 \mathrm{MPa})$, inexpensiveness, nontoxicity, non-flammability, recyclability and environmental benignity. ${ }^{13}$ The extraction with $\mathrm{SC} \mathrm{CO}_{2}$ was used to acquire extracts from over 300 plant species. ${ }^{14,15}$ This technique has already been used to isolate health-promoting compounds from the pomace of a various plants, inter alia, grapes, ${ }^{16}$ tomatoes, ${ }^{17}$ olives, ${ }^{18}$ sour cherries, ${ }^{19}$ and the guelder-rose ${ }^{20}$ and the quality of the extracts has been evaluated. In view of the bio-refinery concept, the nutrient extraction from agrofood industry waste such as skins, stalks and seeds represent a recent challenge. Valorization of by-products for the recovery of oil, phenolic compounds, and fibers by the means of sustainable extraction procedures has gained an increased interest. ${ }^{21}$ Grape is one of the most popular and widely cultivated fruits in the world, but are usually discarded in regular dietary intake and the winery and grape juice industry. Grape seeds and skin are rich in polyphenols, ${ }^{22}$ traditionally, extracted by using organic solvents. ${ }^{23}$ In recent years, according to the biorefinery concept suband supercritical fluid extraction has been utilized as an alternative extraction technique of both polar and non-polar compounds ${ }^{24}$ for processing of a spectrum of marketable products. Extraction efficiency is predisposed by numerous factors such as polarity and concentration of solvent, material-solvent ratio, duration, temperature, $\mathrm{pH}$, etc... Extensive research has been carried out to improve the supercritical fluid extraction (SC extraction) technique to optimize a specific target compound extraction. This research comprises kinetic modelling, ${ }^{25}$ sample preparation and pre-treatment by using pressing, ${ }^{26}$ ultrasonication, ${ }^{27}$ microwave irradiation, ${ }^{28}$ enzyme-assistance ${ }^{29}$ or, within the extraction vessel, ultrasonic-assistance, ${ }^{30}$ and a hydrothermal approach. ${ }^{31}$ Despite there are many review publications on the subject of this review, however, most studies discuss the influence of a single factor has been discussed, while the relations between the factors on the extract yield and composition have not been studied comprehensively. ${ }^{32}$ As process efficiency depends on polarity of the solvent(s) being employed, in SC extraction, polarity of $\mathrm{CO}_{2}$ can be manipulated by process temperature and pressure. Moisture content of the plant raw material also sometimes hinders the product yield, apart from particle size, solvent flow rate, separation conditions employed at separation vessel(s). Besides factors such pressure, temperature, flowrate, sample particle size and moisture content in the material, subjected to the extraction process, addition of co-solvent or modifier enhances extraction efficiency. Particularly if polar compounds are among target ones, co-solvent/modifier could be any polar solvent such as $\mathrm{MeOH}$ or EtOH. However, if safety of the extract is of importance, EtOH with less polarity, though compared to $\mathrm{MeOH}$ could be the option. ${ }^{33}$ Consideration of the optimal processing parameters is extremely important due to the high manufacturing costs associated with SC extraction, resulting from high initial investment costs (associated with high pressure operation/equipment costs) which have been the major limitation preventing its use in industrial processes. The relatively high pressures required to achieve the supercritical point could make the process energy-intensive and economically non-viable which often restricts the use of SC extraction. On the other hand, if SC extraction is utilized as part of a biorefinery rather than as a stand-alone technology, this could lead to a positive effect on the downstream processing of biomass. ${ }^{34}$

Recent investigation has been oriented towards utilization of fruits and their specific parts with a high bioactive compounds content. The main aims of the present study were to maximize the recovery of phenolic compounds in the extracts by application of different extraction methods and variation of experimental parameters. ${ }^{35,36}$ We have been focused mainly on materials that are available in the phytogeographical regions of Slovenia (eg Rosa canina L.) or even constitute waste in processing (grape skin) and have been relatively poorly studied so far.

Due to the low polarity of $\mathrm{CO}_{2}$, EtOH-modified SC $\mathrm{CO}_{2}$ extraction has been performed to obtain extracts with a high phenolic content. Alteration of operating pressure has been assumed to influence the extraction rate of phytochemicals. In the frame of the present research EtOH-modified $\mathrm{SC} \mathrm{CO}_{2}$ extraction has been carried out at $40^{\circ} \mathrm{C}$ and pressures of 150 bar and 250 bar by using EtOH as an entrainer. Conventional extraction methods, such as Soxhlet and maceration have been performed as the reference methods to compare success of the applied methodology. Soxhlet extraction and extraction with cold solvent have been carried out by using $\mathrm{EtOH}$ and $\mathrm{MeOH}$ as solvents since substantial number of scientific reports exist where non-conventional methods using $\mathrm{EtOH}$ and $\mathrm{MeOH}$ as extraction media contributed to the high phenolic recovery. ${ }^{37}$ The effect of extraction technique, temperature, pressure, and solvent on the extraction yield, phenolic 
content and profile along with the estimation of the scavenging activity against the artificial radical $\mathrm{DPPH}^{\star}(2,2$-diphenyl-1-picrylhydrazyl) has been considered. Phenolic profile varied significantly in the extracts obtained from different materials. The highest net content of identified phenolic compounds determined by LC-MS/MS analysis has been determined in the $\mathrm{MeOH}$ extracts of white grapes skin (1,55 mg/g extract), rosehip extract attained by cold extraction with $\mathrm{MeOH}(100 \mathrm{mg} / 100 \mathrm{~g}$ extract), whilst in red grape skin extract the content of phenolic compounds was only about $30 \mathrm{mg} / 100 \mathrm{~g}$ extract.

\section{Experimental}

\section{1. Materials}

All solvents/chemicals used were of analytical/HPLC grade and obtained from Merck, Germany. Folin-Ciocalteu reagent, DPPH, and chemical HPLC-grade standards (purity $\geq 95 \%$ ) of ellagic acid, gallic acid, chlorogenic acid, (+)-catechin, (-)-epicatechin, hesperidin/neohesperidin, myricetin, resveratrol, rutin and caffeic acid were purchased from Sigma-Aldrich (St. Louis, MO, USA).

Lyophilized material was milled and stored in a dry, dark place. Materials were further subjected to extraction experiments.

\section{2. Methods}

\section{Extraction}

Soxhlet extraction: Approximately $20 \mathrm{~g}$ of material was weighed in a filter bag, which was inserted into the cylindrical part of the apparatus. $180 \mathrm{~mL}$ of solvent was heated to reflux. After $240 \mathrm{~min}$ of extraction at a temperature above the solvent boiling point, the solvent was removed from the extract solution by means of a rotary evaporator, yielding the extracted compound, which was later dried and weighed. The samples were stored in a dark and cool place until analyzes.

Cold solvent extraction: Red and white grapes skin were purchased by the local suppliers, the rosehip fruits were donated by Frutarom Etol d.o.o.(Slovenia). The powdered materials $(20 \mathrm{~g})$ were extracted by stirring using a magnetic stirrer with $180 \mathrm{~mL}$ of $\mathrm{MeOH}$ at $25^{\circ} \mathrm{C}$ for $4 \mathrm{~h}$. The extract was filtered for removal of solid particles. The extracts were cooled to room temperature and concentrated under vacuum at $40^{\circ} \mathrm{C}$.

EtOH-modified SC extraction: SC extraction (SCE) experiments were performed on extraction unit previously described in the literature. ${ }^{38}$ The high pressure vessel was loaded with $10 \mathrm{~g}$ of material and placed in a water bath heated to the desired temperature $\left(40^{\circ} \mathrm{C}\right)$. $\mathrm{EtOH}$ was pumped continuously using a high pressure pump with a flow rate of $2 \mathrm{~mL} / \mathrm{min}$. Pressurized $\mathrm{CO}_{2}$ has been introduced in the autoclave from the gas cylinder using a HPLC pump and was kept constant during the entire experiment.
The extract and the solvent were collected in the tubes. The total time of extraction was 100 minutes. Solution was transferred to evaporation flask and the solvent was evaporated using a rotary vacuum evaporator. The mass of the extract was determined gravimetrically and the extraction efficiency was calculated. The extract was stored in a freezer at $-10{ }^{\circ} \mathrm{C}$ until the analyses.

\section{3. Spectrophotometric Analyses}

Determination of total phenolic content, proanthocyanidin concentration in extracts and antioxidant activity was done using UV-visible spectrophotometer (CARY 50 UV-VIS).

\section{Determination of total phenolic content}

Total phenolic content in extracts was determined using Folin-Ciocalteu reagent as described in the literature. ${ }^{39}$ Briefly, the Folin-Ciocalteu reagent solution has been prepared by diluting the basic Folin-Ciocalteu reagent solution with distilled water in a ratio of $1: 10 . \mathrm{Na}_{2} \mathrm{CO}_{3}$ solution has been prepared by weighing approximately $3.75 \mathrm{~g}$ of $\mathrm{Na}_{2} \mathrm{CO}_{3}$ in a $50 \mathrm{~mL}$ volumetric flask, diluted with distilled water to the mark and sonicated until total dissolution of $\mathrm{Na}_{2} \mathrm{CO}_{3}$ was obtained. Approximately $50 \mathrm{mg}$ of the extract was weighted in a $10 \mathrm{~mL}$ volumetric flask and diluted with $\mathrm{MeOH}$. $2.5 \mathrm{~mL}$ of the Folin-Ciocalteu reagent solution and $2 \mathrm{ml}$ of $\mathrm{Na}_{2} \mathrm{CO}_{3}$ were added to $5 \mathrm{~mL}$ of the prepared extract solution. The mixture was left for $30 \mathrm{~min}$ at room temperature $\left(25 \pm 2{ }^{\circ} \mathrm{C}\right)$, then the absorbance of the solution was measured at $765 \mathrm{~nm}$ using a UV-visible spectrophotometer. The total phenolic compounds was determined in triplicate for each sample. The calibration curve of gallic acid was used for quantification of total phenolic compounds and the amount of phenolic compounds in the samples was expressed as gallic acid equivalents, in $\mathrm{mg}$ of gallic acid / $\mathrm{g}$ of material.

\section{Determination of proanthocyanidin content}

The proanthocyanidins were determined by UV spectrophotometry method (Varian-UV-VIS Spectrophotometer) based on acid hydrolysis and colour formation. ${ }^{40}$ The reagent was prepared by weighing $77 \mathrm{mg}$ of $\mathrm{Fe}\left(\mathrm{SO}_{4}\right) \times$ $7 \mathrm{H}_{2} \mathrm{O}$ and adding $500 \mathrm{~mL}$ of $\mathrm{HCl}$ : butanol solution $(200$ $\mathrm{mL} \mathrm{HCl}$ and $300 \mathrm{~mL}$ of butanol). $50 \mathrm{mg}$ of the extract was weighted into a $10 \mathrm{~mL}$ volumetric flask and filled with $\mathrm{MeOH}$ to the mark. After the entire extract is dissolved, $1.0 \mathrm{~mL}$ of the extract solution was mixed with $10 \mathrm{~mL}$ of iron sulphate solution. At the same time, a control sample was prepared; instead of the extract solution, the same amount of $\mathrm{MeOH}$ was added to iron sulphate solution. The samples were thermostated for 15 minutes at a water bath at $95{ }^{\circ} \mathrm{C}$. The solutions were cooled and the absorbance was measured at $540 \mathrm{~nm}$. The concentration of proanthocyanidins (PAC) in the extract solution is expressed as $\mathrm{mg}$ $\mathrm{PAC} / \mathrm{mL}$ of extract solution. 


\section{DPPH Radical Scavenging Assay}

Radical scavenging activity of extracts was measured using the stable radical DPPH (2,2-diphenyl-picryl-hydrazil) reagent. $50 \mu \mathrm{L}$ of extract solution in $\mathrm{MeOH}$ was added to $1.95 \mathrm{~mL}$ of the $\mathrm{MeOH}$ solution of DPPH $(0.025 \mathrm{~g} / \mathrm{L})$. In parallel, a negative control was prepared by mixing $50 \mu L$ of $\mathrm{MeOH}$ with $1.95 \mathrm{~mL}$ of the $\mathrm{MeOH}$ solution of DPPH. After 15 min of incubation in the dark at room temperature, the absorbance was measured at $517 \mathrm{~nm}$ against a blank sample. An ascorbic acid was used as positive control of an antioxidant reference, measured at the same conditions as samples. For each concentration, the test is repeated 3 times. The absorbance is measured by the UV-Vis spectrophotometer.

\section{4. Chromatographic Analyses}

LC-MS/MS analysis: For identification and quantification of detected phenolic compounds, the Agilent 1200 HPLC in tandem with Agilent 6460 QQQ with JetStream ionization was used. The HPLC apparatus was equipped by quaternary HPLC high pressure pump, automatic sampler and column thermostat. The chromatographic separation of the compounds was performed on analytical column Agilent Eclipse Plus, $150 \mathrm{~mm} \times 4.6 \mathrm{~mm}$ i.d., $1.8 \mu \mathrm{m}$ particle size. The column was maintained at $35{ }^{\circ} \mathrm{C}$. The elution gradient consisted of mobile phase A (water with addition of 0.1 vol.\% of formic acid) and mobile phase B (acetonitrile with addition of 0.1 vol.\% of formic acid). The flow rate was $0.5 \mathrm{~mL} / \mathrm{min}$ using gradient program as follows: 0 min 5\% B, 5 min $18 \%$ B, 10 min, 30\% B, 15 min $35 \%$ B, 20 min $50 \%$ B, 21 min 70\% B and at 25 min back to $5 \%$ of B. Samples, subjected to the analyses, were prepared by weighing approximately $100 \mathrm{mg}$ of the extract in a 10 $\mathrm{mL}$ volumetric flask and diluted with $\mathrm{MeOH}$ up to $10 \mathrm{~mL}$. Prepared samples were filtered through $0.2 \mu \mathrm{m}$ syringe filter and injected (volume of $5 \mu \mathrm{L}$ ) into the system. The multiple reaction monitoring (MRM) mode was used to quantify the analytes, where the assay of was performed following two transitions per compound, the first one for quantitative purposes and the second for confirmation. The optimum ESI conditions were determined: gas temperature $300^{\circ} \mathrm{C}$, gas flow $6 \mathrm{~L} / \mathrm{min}$, nebulizer $45 \mathrm{psi}$ (nitrogen), sheath gas temperature $250^{\circ} \mathrm{C}$, sheath gas flow $11 \mathrm{~L} /$ min, capillary $3500 \mathrm{~V}$ and nozzle voltage $500 \mathrm{~V}$ at delta EMV 200 in negative ionization.

\section{Results and Discussion}

\section{1. Conventional and SC Extraction}

Results in Figure 1 indicate that $\mathrm{MeOH}$ was an efficient solvent for extraction of red grapes skin using Soxhlet apparatus. Soxhlet extraction with $\mathrm{MeOH}$ gave the total mass yield of approx. $72 \%$, while cold solvent extraction with $\mathrm{MeOH}$ gave a yield of approx. 50\%. In general

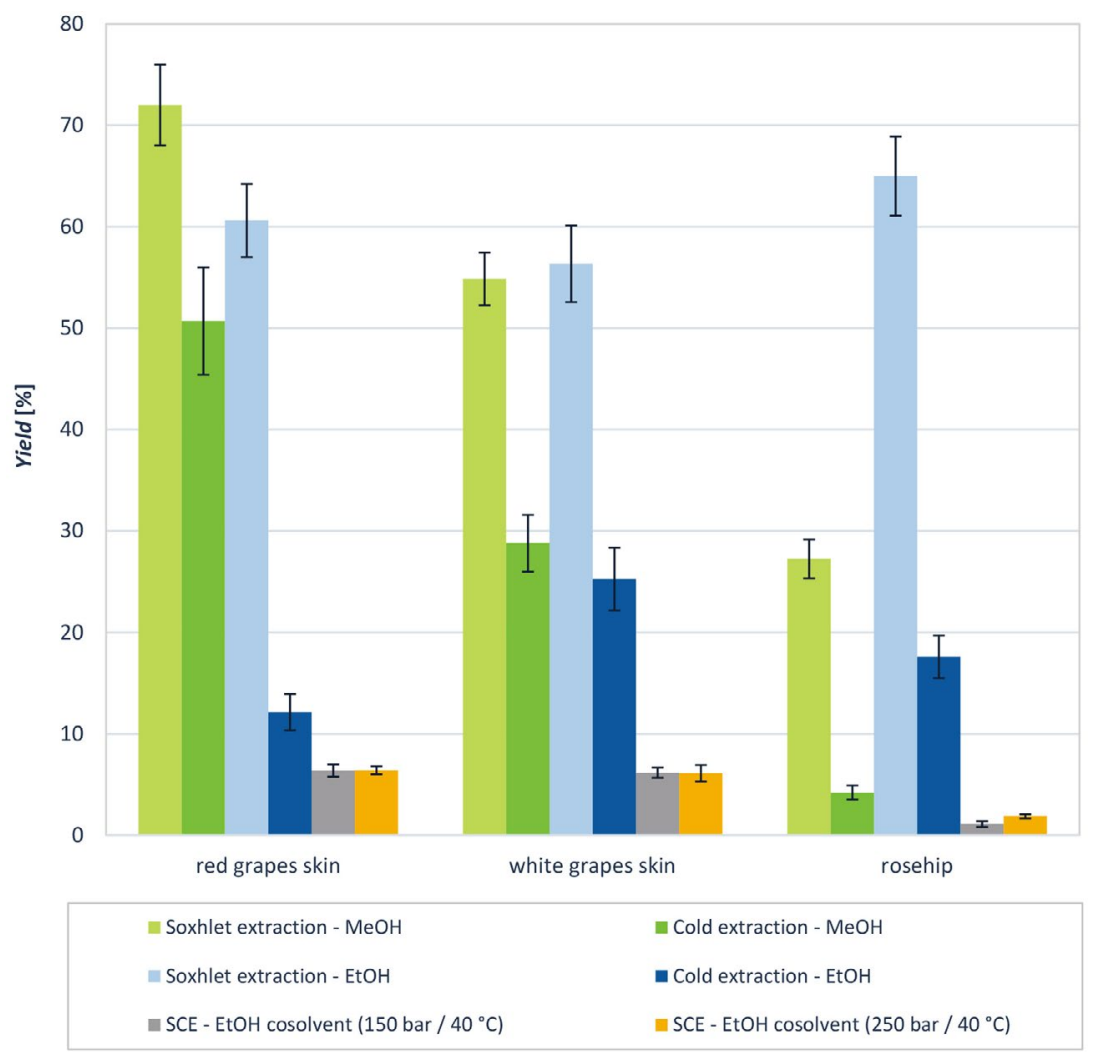

Figure 1: Comparison of extraction yield of red, white grapes skin and rosehip using different extraction methods. 
the extraction yield decreased with decreasing solvent temperature. Likewise, for the extraction of white grapes skin and rosehip, the $\mathrm{MeOH}$ was more efficient extraction media at elevated temperatures. For white grapes skin, the total extraction yield was $54.9 \%$ by using Soxhlet extraction and only $28.8 \%$ by cold extraction. Rosehip extraction by $\mathrm{MeOH}$ gave relatively low yields, about $27.5 \%$ by Soxhlet and only $4.2 \%$ by cold extraction. Higher solvent temperature apparently contributed to a higher extraction yield. EtOH was demonstrated as a less efficient solvent considering the total mass yield for both kinds of grapes skin. However, the yields were higher when utilizing hot solvent for all of the examined materials. Soxhlet extraction gave yields ranging from $56.4 \%$ for white grape skin and up to $65 \%$ for rosehip. Cold extraction of white grape skin gave a maximum yield approx. $25 \%$.

In addition, Figure 1 demonstrates that the extractions of grape skin (red and white) gave high yields with $\mathrm{MeOH}$ and $\mathrm{EtOH}$. Consequently, it can be confirmed that $\mathrm{MeOH}$ and $\mathrm{EtOH}$ are a good choice for the solvent in the extraction of grapes, because they have high polarity and are therefore very good solvents for polyphenolic components, including resveratrol. The temperature has a significant effect in the extraction process. For instance, for red and white grape skin, it can be noticed that cold extraction yielded twice as low of extract as Soxhlet's extraction, regardless of solvent used. The same applies to rosehip, as this material also gets lower extraction efficiency than in extraction with higher temperatures. The relative polarity of the $\mathrm{MeOH}$ is higher than polarity of $\mathrm{EtOH}$, due to this extraction efficiency of white and red grapes is higher when $\mathrm{MeOH}$ was used as a solvent media. In that case, the polarity of the solvent influences the extraction yields. Higher temperatures usually lead to higher yields of extraction. SC extraction gave lower mass yields compared to conventional extraction methods, despite the use of $\mathrm{EtOH}$ as entrainer. Beside the low solvent polarity, low extraction temperature may have also contributed to the low extraction yield. The highest yield, approx. $6.4 \%$ has been attained by red grapes skin extraction at 250 bar, similar as for the white grape skin, where the yield was about $6.2 \%$. Supercritical extraction (SC extraction) of the rosehip gave yields only somewhat higher than $1.86 \%$. The effect of pressure has also been investigated and it was considered that the pressure does not have a tremendous effect on the extraction efficiency, since very similar yield have been attained at 150 and 250 bar for the same materials, except for the rosehip, where higher pressure gave higher yield.

\section{2. Total Phenolic Content in Extracts}

Comparison of total phenolic content, expressed as $\mathrm{mg}$ of gallic acid/g of extract (mgGA/gEXT) at different extraction procedures is given in Figure 2. The concentration of total phenolic compounds in extracts ranged from $8.49 \mathrm{mg}$ of gallic acid per $\mathrm{g}$ of extract to $21.66 \mathrm{mg}$ of gallic acid per $\mathrm{g}$ of extract for grape skin, depending on solvent selection and temperature during the extraction process. The highest concentration of phenolic compounds for conventional extraction procedure was $25.61 \mathrm{mg}$ of gallic

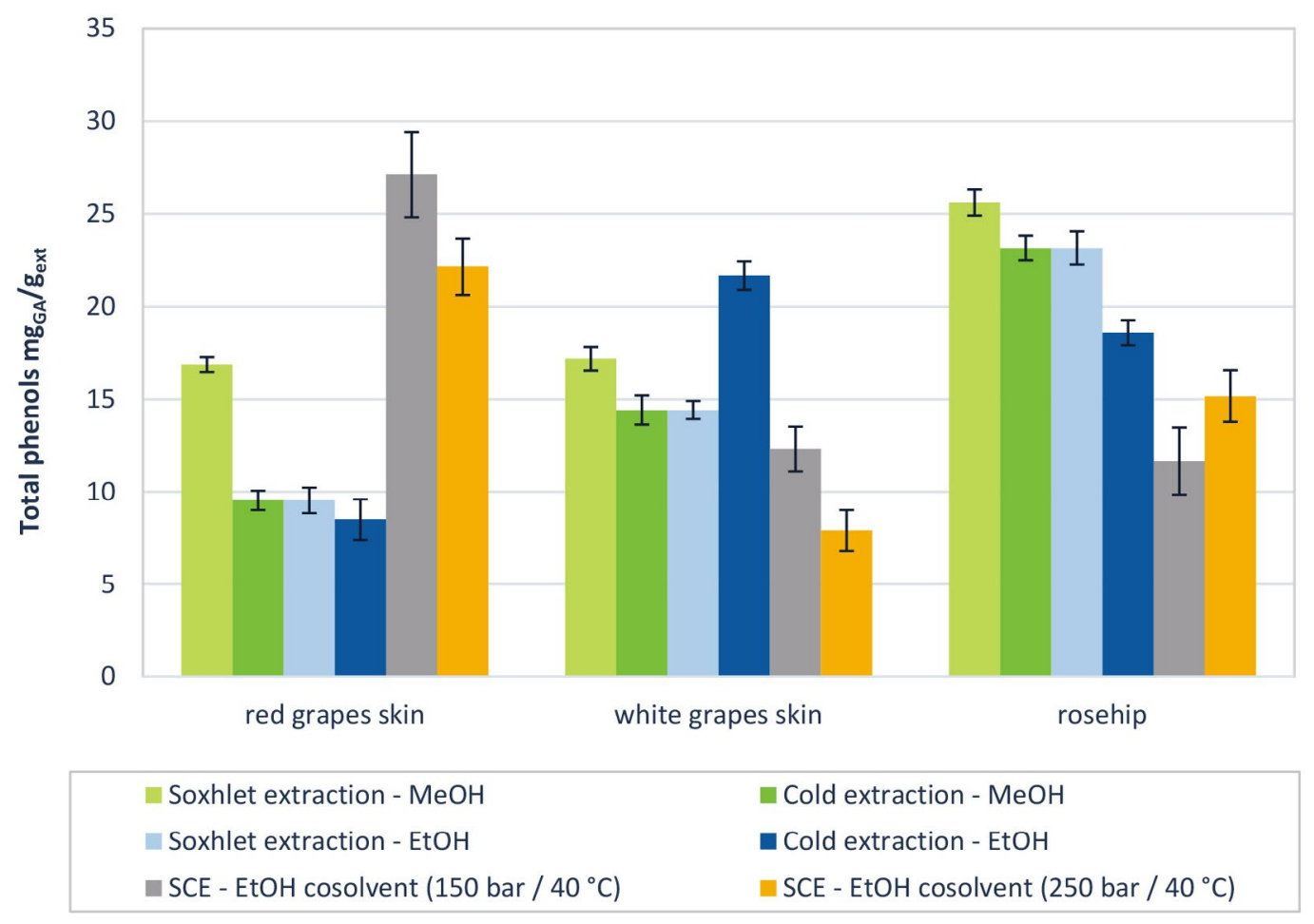

Figure 2: Comparison of total phenolic content, expressed as $\mathrm{mg}$ of gallic acid/g of extract $\left(\mathrm{mg}_{\mathrm{GA}} / \mathrm{g}_{\mathrm{EXT}}\right)$ at different extraction procedures. 
acid per $\mathrm{g}$ of extract in red grape extract. In general, Soxhlet extraction with $\mathrm{MeOH}$ gave higher concentrations of phenolic compounds in comparison with EtOH.

In extracts obtained with SC extraction method, the concentration of total phenolic compounds ranged from $7.9 \mathrm{mg}$ of gallic acid per $\mathrm{g}$ of extract to $27.12 \mathrm{mg}$ of gallic acid per $\mathrm{g}$ of extract. The highest content was determined in extracts from red grape skin, attained at 150 bar and 40 ${ }^{\circ} \mathrm{C}$. The content varied depending on pressure during the extraction process; the content in the extract, attained at $250 \mathrm{bar}$ and $40{ }^{\circ} \mathrm{C}$ was $22.15 \mathrm{mg}$ of gallic acid per g of extract.

The concentration of phenolic compounds in white grape skin extract was $8.83 \mathrm{mg}$ of gallic acid per g of extract at 150 bar and $40^{\circ} \mathrm{C}$, whilst at higher extraction pressure the concentration decreased to $6.77 \mathrm{mg}$ of gallic acid per $g$ of extract. In general, from both grape skin, higher concentrations of phenolic compounds have been attained at lower extraction pressure. On the contrary, in case of rosehip, the content increased with elevation of extraction pressure from $8.13 \mathrm{mg}$ of gallic acid per $\mathrm{g}$ of extract at 150 bar and $40{ }^{\circ} \mathrm{C}$ up to $9.01 \mathrm{mg}$ of gallic acid per g of extract at 250 bar and $40^{\circ} \mathrm{C}$.

Also, the influence of temperature during the extraction process on the total amount of phenols in extracts was noticed. Extraction of both grape skin and rosehip with $\mathrm{MeOH}$ at its boiling point resulted higher amount of phe- nolic compounds compared to the amount of phenolics in case of cold extraction with $\mathrm{MeOH}$. In general, higher extraction temperature contributed to higher concentration of phenolic compounds except in case of cold extraction of white grape skin with $\mathrm{EtOH}$, which was more efficient for extraction of phenolic compounds. White grape skin extract contains more phenolic compounds in comparison with red grapes skin.

\section{3. Proanthocyanins in Extracts}

The amount of proanthocyanins (PAC) in the extracts obtained by Soxhlet, cold and SC extraction is presented in Figure 3. The highest concentration of proanthocyanins was obtained in white grapes skin by cold extraction with $\mathrm{MeOH}(2.02 \mathrm{mg}$ PAC $/ \mathrm{mL})$. It can be observed that white grapes have higher amount of proanthocyanins in comparison with red grapes skin, where the content of proanthocyanins was highest in the extract attained by Soxhlet extraction with $\mathrm{MeOH}$ (1.34 mg PAC / $\mathrm{mL}$ ). The concentration of proanthocyanins in rosehip extracts was the lowest, up to $0.96 \mathrm{mg} / \mathrm{mL}$ PAC in the extract obtained by cold extraction with $\mathrm{MeOH}$.

The highest concentration of proanthocyanins obtained by modified SC extraction was determined in rosehip extracts attained at 250 bar and $40{ }^{\circ} \mathrm{C}$; approximately $0.69 \mathrm{mg} \mathrm{PAC} / \mathrm{mL}$. The amount of extracted proanthocya-

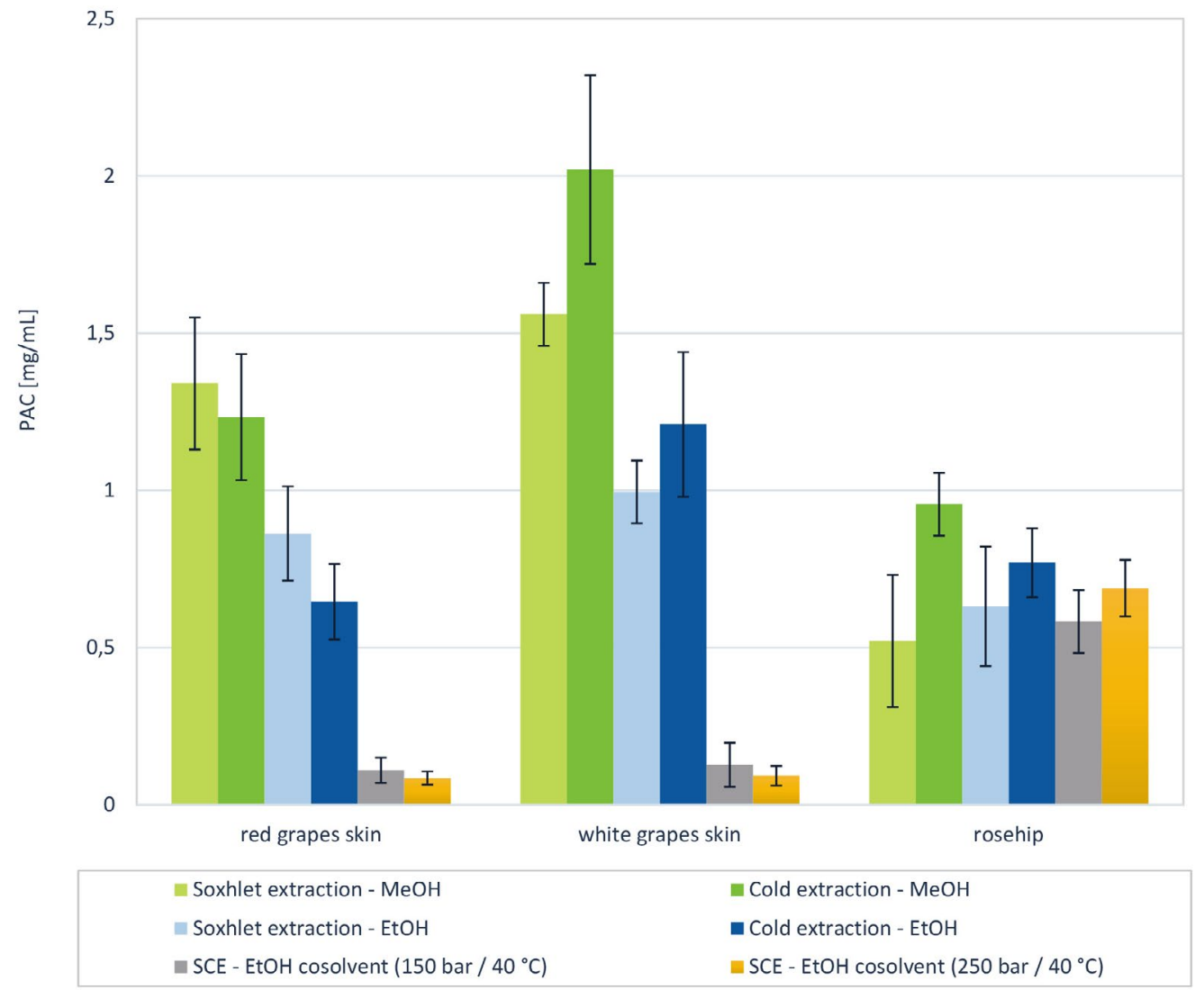

Figure 3: Comparison of proanthocyanins content in extracts obtained by Soxhlet, cold and SC extraction. 
nins in rosehip extracts decreased with decreasing extraction pressure to $0.583 \mathrm{mg}$ PAC $/ \mathrm{mL}$ ).

It was found, that white grapes have slightly higher amount of proanthocyanins in comparison with red grapes skin. The content of proanthocyanins was highest in the white grape skin extract attained at 150 bar and $40{ }^{\circ} \mathrm{C}$; approximately $0.13 \mathrm{mg} \mathrm{PAC} / \mathrm{mL}$ and about $0.09 \mathrm{mg} \mathrm{PAC} /$ $\mathrm{mL}$ in extract attained at $250 \mathrm{bar}$ and $40{ }^{\circ} \mathrm{C}$. The concentration of proanthocyanins in red grapes skin extracts was the lowest, up to $0.11 \mathrm{mg} \mathrm{PAC} / \mathrm{mL}$ at 150 bar and $40{ }^{\circ} \mathrm{C}$ and only $0.085 \mathrm{mg} \mathrm{PAC} / \mathrm{mL}$ at 250 bar and $40{ }^{\circ} \mathrm{C}$. Almost three times higher concentration of proanthocyanins was obtained in white grapes skin obtained by cold extraction with $\mathrm{MeOH}(2.02 \mathrm{mg} \mathrm{PAC} / \mathrm{mL})$.

\section{4. LC/MS Analysis}

The phenolic compounds were analyzed using LCMS/MS analytical method. The identification and quantification of individual phenolic compound was done using analytical standards of each compound and the calculation was done using calibration curves, as described in section 2.4 .

The content of phenolic compounds in extracts is shown in Table 1. The highest content of the identified phenolic compounds was present in $\mathrm{MeOH}$ extracts of white grape skin, whereas the major compound was cate- chin $(0.980 \mu \mathrm{g} / \mathrm{mg}$ extract). EtOH extracts gave lower phenolics recovery, apparently by decreasing solvents polarity less phenolics were dissolved. EtOH white grape skin extract contained approximately a half of the identified compounds when utilizing Soxhlet procedure, again, catechin was the major compound $(0.438 \mu \mathrm{g} / \mathrm{mg}$ extract $)$, whilst the cold solvent extract contained only $0.085 \mu \mathrm{g} / \mathrm{mg}$ extract, which is ten times lower than in case of $\mathrm{MeOH}$ extracts. Gallic acid was the major compound in SC extracts of white grapes skin $(0.080 \mu \mathrm{g} / \mathrm{mg}$ extract), higher pressure contributed to somewhat higher content. The major compound in red grape skin extract was ellagic acid $(0.050 \mu \mathrm{g} /$ mg extract), its recovery increased with increasing solvent polarity, whilst effect of temperature was not explicit. Caffeic acid was also identified, the highest content was present in the $\mathrm{MeOH}$ extract. Gallic, ellagic acid and resveratrol were identified in SC extracts. Likewise, rosehip extracts mainly contained caffeic, gallic, ellagic acid and resveratrol, although the highest recovery of ellagic acid was analyzed in $\mathrm{MeOH}$ extract. Resveratrol was detected only in SC extracts. However, the highest recovery of resveratrol was observed in SC extract of white grape skin attained at $250 \mathrm{bar}$ and the macerated white grape skin extracts $(0.03 \mu \mathrm{g} / \mathrm{mg}$ extract $)$. Rutin and hesperidin were present in lower concentration, however, $0.068 \mu \mathrm{g} / \mathrm{mg}$ extract of rutin was analyzed in $\mathrm{MeOH}$ extract of red grapes skin, whereas the content of hesperidin/neohesperidin

Table 1: Content of phenolic compounds in the extracts of white and red grape skin and rosehip at different extraction conditions.

\begin{tabular}{|c|c|c|c|c|c|c|c|c|c|c|}
\hline Compound & $\begin{array}{l}\text { caffeic } \\
\text { acid } \\
\mathrm{ug} / \mathrm{mg}\end{array}$ & $\begin{array}{l}\text { cate- } \\
\text { chin } \\
\mathrm{ug} / \mathrm{mg}\end{array}$ & $\begin{array}{c}\text { chloroge- } \\
\text { nic acid } \\
\text { ug/mg }\end{array}$ & $\begin{array}{l}\text { ellagic } \\
\text { acid } \\
\mathrm{ug} / \mathrm{mg}\end{array}$ & $\begin{array}{l}\text { epica- } \\
\text { techin } \\
\mathrm{ug} / \mathrm{mg}\end{array}$ & $\begin{array}{l}\text { gallic } \\
\text { acid } \\
\mathrm{ug} / \mathrm{mg}\end{array}$ & $\begin{array}{c}\text { hesperidin/ } \\
\text { neohespe- } \\
\text { ridin } \\
\mathrm{ug} / \mathrm{mg}\end{array}$ & $\begin{array}{l}\text { resve- } \\
\text { ratrol } \\
\mathrm{ug} / \mathrm{mg}\end{array}$ & $\mathrm{ug} / \mathrm{mg}$ & $\mathrm{mg} / 100 \mathrm{~g}$ \\
\hline $\begin{array}{l}\text { White grapes skin, } \\
\text { Cold - MeOH }\end{array}$ & 0.013 & 0.838 & 0.001 & 0.043 & 0.340 & 0.074 & 0.015 & 0.030 & 0.015 & 1.370 \\
\hline $\begin{array}{l}\text { White grape skin, } \\
\text { Soxhlet - MeOH }\end{array}$ & 0.016 & 0.980 & 0.007 & 0.044 & 0.346 & 0.096 & 0.012 & 0.027 & 0.023 & 1.550 \\
\hline $\begin{array}{l}\text { White grape skin } \\
\text { Soxhlet - EtOH }\end{array}$ & 0.011 & 0.438 & 0.002 & 0.025 & 0.212 & 0.050 & 0.008 & 0.015 & 0.012 & 0.773 \\
\hline $\begin{array}{l}\text { White grapes skin, } \\
\text { Cold - EtOH }\end{array}$ & 0.012 & 0.085 & 0.002 & 0.019 & 0.038 & 0.034 & 0.003 & 0.011 & 0.002 & 0.207 \\
\hline $\begin{array}{l}\text { White grapes skin } \\
-150 \text { bar }\end{array}$ & 0.014 & 0.028 & 0.006 & 0.027 & 0.015 & 0.071 & 0.009 & 0.020 & 0.009 & 0.199 \\
\hline $\begin{array}{l}\text { White grapes skin } \\
-250 \mathrm{bar}\end{array}$ & 0.015 & 0.056 & 0.002 & 0.022 & 0.024 & 0.080 & 0.003 & 0.029 & 0.000 & 0.230 \\
\hline $\begin{array}{l}\text { Red grapes skin, } \\
\text { Cold - MeOH }\end{array}$ & 0.025 & 0.009 & 0.001 & 0.050 & 0.009 & 0.016 & 0.033 & 0.007 & 0.100 & 0.249 \\
\hline $\begin{array}{l}\text { Red grapes skin, } \\
\text { Cold - EtOH }\end{array}$ & 0.012 & 0.003 & 0.001 & 0.013 & 0.004 & 0.014 & 0.008 & 0.006 & 0.022 & 0.084 \\
\hline $\begin{array}{l}\text { Red grapes skin, } \\
\text { Soxhlet - MeOH }\end{array}$ & 0.019 & 0.090 & 0.006 & 0.018 & 0.021 & 0.027 & 0.038 & 0.014 & 0.068 & 0.301 \\
\hline $\begin{array}{l}\text { Red grapes skin, } \\
\text { Soxhlet - EtOH }\end{array}$ & 0.029 & 0.019 & 0.004 & 0.022 & 0.005 & 0.023 & 0.012 & 0.011 & 0.032 & 0.157 \\
\hline Red grapes skin, 250 bar & 0.038 & 0.000 & 0.001 & 0.014 & 0.002 & 0.016 & 0.001 & 0.012 & 0.000 & 0.083 \\
\hline Rosehip, HT, MeOH & 0.014 & 0.164 & 0.017 & 0.650 & 0.021 & 0.133 & 0.003 & I & 0.000 & 1.003 \\
\hline Rosehip, 150 bar & 0.019 & 0.012 & 0.011 & 0.373 & 0.004 & 0.116 & 0.003 & 0.022 & 0.000 & 0.560 \\
\hline Rosehip, 250 bar & 0.014 & 0.014 & 0.005 & 0.145 & 0.004 & 0.106 & 0.002 & 0.015 & 0.001 & 0.306 \\
\hline
\end{tabular}


was about $0.03 \mu \mathrm{g} / \mathrm{mg}$ extract in the same extract. All extraction procedures gave similar yield of epicatechin (up to $0.346 \mu \mathrm{g} / \mathrm{mg}$ ). Chlorogenic acid was present in traces, up to $0.02 \mu \mathrm{g} / \mathrm{mg}$ extract in $\mathrm{MeOH}$ and SC extract of rosehip.

Among all the extracts, the highest content of caffeic acid $\left(0.038 \mathrm{ug} / \mathrm{mg}_{\text {raw material }}\right)$ has been present in red grapes skin extract, attained at 250 bar and $40{ }^{\circ} \mathrm{C}$. Rosehip extract attained at 150 bar contained up to $0.373 \mathrm{ug} / \mathrm{mg}_{\text {raw material }}$ ellagic acid. The content of resveratrol was low in all samples, however, the highest contents were present in the $\mathrm{MeOH}$ extracts and white grapes skin extracts, attained by $\mathrm{SC}$ extraction at $250 \mathrm{bar}$, up to $0.030 \mathrm{ug} / \mathrm{mg}_{\text {raw material. }}$

\section{5. DPPH Activity of Extracts}

The results of $\mathrm{DPPH}^{*}$ radical scavenging activities of conventional extracts obtained using Soxhlet or cold extraction are presented on Figure 4 and vary between 2.75\% to $13.64 \%$, depending on solvent and method used. The highest $\mathrm{DPPH}^{\star}$ radical scavenging inhibitory activity $13.64 \%$ was observed for red grapes skin extract prepared by cold extraction with $\mathrm{MeOH}$ as solvent. $\mathrm{DPPH}^{*}$ radical scavenging inhibitory activity for white grape skin were slightly lower, but trend is similar. In general, for grape skin solvent $\mathrm{MeOH}$ resulted higher $\mathrm{DPPH}^{\star}$ radical scavenging. Results obtained for grape skin show that extracts, attained by the cold extraction method exhibited higher $\mathrm{DPPH}^{*}$ radical scavenging comparison to extracts attained by Soxhlet extraction. In case of rosehip extraction, Sox- hlet extraction gave extracts with higher $\mathrm{DPPH}^{\star}$ radical scavenging activity regardless of the solvent used. Higher extraction yield does not necessarily mean higher biological activity of the extracts. The use of different solvents can result in the extraction of various types of metabolites from extracted material, with varying radical scavenging activities. Furthermore, increased temperatures during the extraction process may result in denaturation and a reduction of the loss of ability to act as an antioxidant.

The results of $\mathrm{DPPH}^{*}$ radical scavenging activities of extracts obtained using modified SC extraction vary between $6.67 \%$ and $11.68 \%$, depending on the material. The highest $\mathrm{DPPH}^{\star}$ radical scavenging inhibitory activity was observed for red grapes skin extract, attained at 150 bar and $40{ }^{\circ} \mathrm{C}$. The activity is lower in the extract, attained at 250 bar and $40{ }^{\circ} \mathrm{C} ; 9.23 \%$.

$\mathrm{DPPH}^{*}$ radical scavenging inhibitory activities for white grape skin were slightly lower in both extracts compared to the red grape skin extracts. Lower extraction pressure again resulted in somewhat higher scavenging activity of the extract; approximately $8.83 \%$, whilst the extract attained at 250 bar showed somewhat lower inhibition ability, approximately $6.67 \%$.

Rosehip extracts showed similar scavenging inhibitory activity as the extracts of white grape skin. However, in this case higher extraction pressure contributed to somewhat higher scavenging activity $(9.01 \%)$, whilst the extract attained at 150 bar showed lower inhibition ability, approximately $8.13 \%$. The use of different process condi-

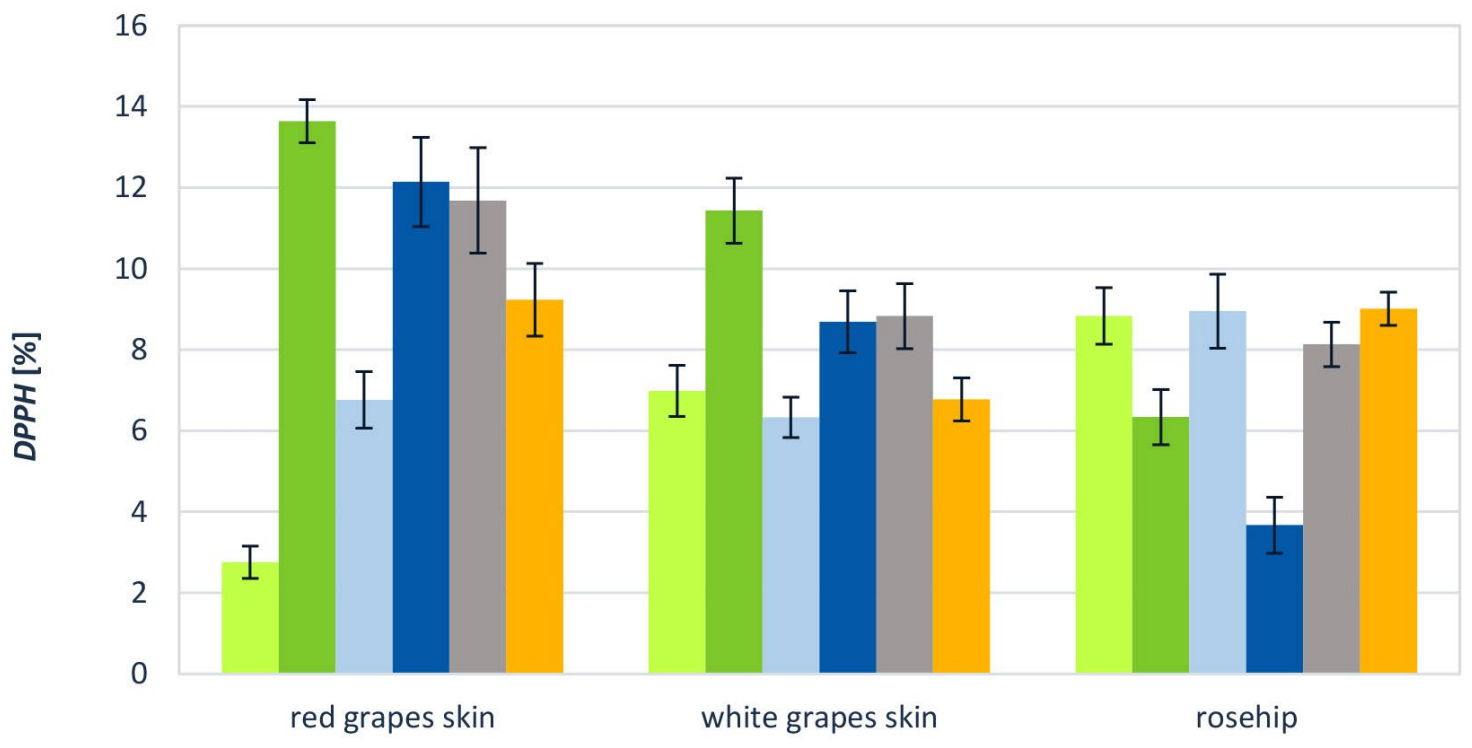
Soxhlet extraction - $\mathrm{MeOH}$
Cold extraction - $\mathrm{MeOH}$
Soxhlet extraction - EtOH
Cold extraction - EtOH
a SCE - EtOH cosolvent (150 bar / $\left.40^{\circ} \mathrm{C}\right)$
SCE - EtOH cosolvent $\left(250 \mathrm{bar} / 40^{\circ} \mathrm{C}\right)$

Figure 4: Comparison DPPH activity in \% using different extraction procedures. 
tions can result in the extraction of various types of metabolites from extracted material, with varying radical scavenging activities. In general, the amount of proanthocyanins and the total phenolic content is not directly related to the radical scavenging inhibitory activities. Red grapes skin extracts prepared by cold extraction and SC extraxtion exhibited similar scavenging inhibitory activities (ranging from 9\% up to nearly 14\%), whilst the contents of proanthocyanins and the total phenolics ranged from $0.085 \mathrm{mg}$ PAC $/ \mathrm{mL}$ in extract attained by SC extraction at 250 bar and $40{ }^{\circ} \mathrm{C}$ up to $1.233 \mathrm{mg}$ PAC $/ \mathrm{mL}$ in cold $\mathrm{MeOH}$ extract, which exhibited highest inhibitory activity. Meanwhile, the concentration of total phenolic compounds in that extract was $9.53 \mathrm{mg}$ of gallic acid per $\mathrm{g}$ of extract. Amongst all red grape skin extracts the lowest $\mathrm{DPPH}^{\star}$ was determined for Soxhlet extract prepared with $\mathrm{MeOH}$, where the contents of proanthocyanins was the highest (1.34 PAC /mL).

Amongst all white grape skin extracts the highest $\mathrm{DPPH}^{*}(11.43 \%)$ was determined for $\mathrm{MeOH}$ extract prepared by cold extraction; the concentration of proanthocyanins was high, $2.02 \mathrm{mg}$ PAC $/ \mathrm{mL}$, and the total phenolics content was about $14.41 \mathrm{mg}$ of gallic acid per g of extract. Both Soxhlet extracts of rosehip exhibited similar scavenging activities (about 9\%). Similar value was measured for extract, attained at $250 \mathrm{bar}$ and $40^{\circ} \mathrm{C}$. The concentration of proanthocyanins was the highest for $\mathrm{MeOH}$ extract prepared by cold extraction; $0.956 \mathrm{PAC} / \mathrm{mL}$, whilst total phenolics content was about $24 \mathrm{mg}$ of gallic acid per $\mathrm{g}$ of extract.

\section{Conclusion}

The obtained results confirm earlier findings that rosehip, white and red grape skin are potentially good sources of natural antioxidants. Although, the content of total phenolics differs depending on the type of material, isolation method and applied solvent. Besides, anthocyanin content in grape skin can depends on the variety and the harvest year.

According to the previous research, ${ }^{41}$ the conventional extraction methods involving organic solvents and increased temperature yielded more total phenols. The present results show that the amount of anthocyanins depends on the plant material and extraction solvent. Regardless of the method and solvent used, the highest content of total phenolic compounds $\left(27.12 \mathrm{mg}_{\mathrm{GA}} / \mathrm{g}_{\mathrm{EXT}}\right)$ has been determined in the extracts from red grape skin, obtained at 150 bar and $40{ }^{\circ} \mathrm{C}$. High content of total phenolic compounds was, according to their polar nature, determined also in extracts, obtained by conventional extraction with $\mathrm{MeOH}$; up to $25.61 \mathrm{mg}_{\mathrm{GA}} / \mathrm{g}$ of red grape skin extract. In general, Soxhlet extraction using $\mathrm{MeOH}$ gave higher concentrations of phenolic compounds in comparison to extractions using $\mathrm{EtOH}$. In addition, the higher extraction temperatures contributed to higher concentration of phenolic compounds. The content of proanthocyanins in extracts obtained by modified SC extraction was the lowest in all extracts.

According to the analyses, the yield of phenolic compounds in extracts attained by SC extraction was lower than in the extracts attained by the conventional solvent extraction. This may be explained by the fact that $\mathrm{CO}_{2}$ usually yields good recoveries for nonpolar compounds, but polar compounds may remain partially unextracted because of their lower solubility in this fluid. For this reason, EtOH as organic modifier has been added as cosolvent to the primary fluid to boost the extraction effectiveness. The extraction output considering mass yield was higher in case of conventional extraction methods, but the amount of anthocyanins and phenols successfully extracted with supercritical solvent is considerable. The results show, that generally $\mathrm{SC} \mathrm{CO}_{2}$ in combination with a polar entrainer, represents a good extraction media for isolation of total phenols, while the amount of extracted anthocyanins is low. LC-MS/MS analyses show that gallic, ellagic acid and resveratrol were identified in SC extracts. Therefore, we could consider that $\mathrm{SC}$ extraction with $\mathrm{CO}_{2}$ therefore provides an alternative method to replace extractions with organic solvents for the recovery of phenolic compounds. In general, SC extraction was less efficient due to the limited solvent polarity. Despite the lower total mass yield and the proportion of total phenols in extracts compared to the conventionally obtained extracts, the method was efficient for isolation of caffeic acid, galic and elagic acid.

$\mathrm{DPPH}^{\star}$ radical scavenging activities of extracts obtained using modified SC extraction and conventional extraction are similar and depend on the type of material. Highest $\mathrm{DPPH}^{\star}$ radical scavenging inhibitory activity was observed for red grapes skin using cold extraction and $\mathrm{MeOH}$ as solvent (about 13\%), where the content of total phenols was $9.53 \mathrm{mg}$ of gallic acid per $\mathrm{g}$ of extract. The activity of supercritical extract attained at 150 bar and 40 ${ }^{\circ} \mathrm{C}$ was only slightly lower, about $12 \%$, whilst the content of total phenols was the highest, $27.12 \mathrm{mg}$ of gallic acid per $\mathrm{g}$ of extract.

The primary aim of this work was utilization of SC extraction for isolation of phenolic compounds as a sustainable method which involves lower consumption of organic solvents. Besides, SCFs are generally cheap, simple, and comparatively safe solvents which is of special attractiveness for industrial processes (especially in food and pharmaceutical applications). Toxic hazards from solvent manipulation are greatly reduced as well as disposal costs. Another motivation for developing processes involving SCFs as solvents SC extraction processes is the reduction or even complete elimination of residual solvents in the products, lower operating temperatures and prevention of oxidation during processing. In contrast to various organic solvents, SCFs can be more simply recycled which signifi- 
cantly reduces the cost of any analytical procedure. The union between economic feasibility and safety are getting more consideration and indeed, safer and less harmful solvents that are easy to remove, or recover, are gaining in popularity in the favor of SC extraction. If certain parameters (absence of organic solvents, lower processing temperatures, shorter processing times, no need for further purification of the extract) are taken into account, a high value product can be obtained for a relatively low price. Laboratory-scale data can be safely used to develop economic evaluations of the SC extraction process, as the tendency of the process is to improve yield with increasing scale.

In terms of product quality and environmental issues, compared to conventional extraction processes, SC extraction can be regarded as a more suitable alternative for processing heat-sensitive materials, providing appropriate conditions to maintain the functional properties of the extract.

\section{Acknowledgements}

The authors would like to acknowledge the Slovenian Research Agency (ARRS) for financing this research in the frame of Program P2-0046 (Separation processes and production design) and Project J2-1725.

\section{Author biographies}

Dr. Maša Knez Hrnčič holds a PhD in Chemical Engineering from the Faculty of Chemistry and Chemical Engineering, University of Maribor, where she is employed as an Assistant Professor. Her past work experience include research work at several foreign universities (University of Alabama at Birmingham, Graz University of Technology, University of Fresno). She has also established herself as a research project leader. Her main areas of research are separation processes, phase equilibria, green chemistry.

Dr. Darija Cör is a Researcher Assistant with a PhD obtained at the Faculty of Chemistry and Chemical Engineering, University of Maribor. During her $\mathrm{PhD}$ her research was focused on extraction of biological materials using subcritical and supercritical fluids. She has wide experience in high pressure technologies and analytical techniques (gas and liquid chromatography, UV-VIS spectroscopy, Differential scanning calorimetry...)

Dr. Petra Kotnik received her $\mathrm{PhD}$ in 2014 at the Faculty of Chemistry and Chemical Engineering, University of Maribor, where she works as an Assistant with $\mathrm{PhD}$ in the Laboratory for Separation Processes and Product Design. Her main research activity covers extraction with high pressure technologies, supercritical chromatography, analytical techniques (liquid and gas chromatography with mass spectrometry, UV/VIS spectroscopy).

Professor Dr. Željko Knez earned his PhD in Chemical Engineering in 1984 at the University of Maribor, where he currently works as a Vice dean for research at the Faculty of Chemistry and Chemical Engineering. His expertise are separation processes and product design using sub- and supercritical fluids. He has published over a 295 articles in scientific journals, and his bibliography also includes 25 patents and patent applications. He was president and a member of WP "High pressure technologies" of EFCE and a head of several research projects.

\section{References}

1. E. Brglez Mojzer, M. Knez Hrnčič, M. Škerget, Ž. Knez, U. Bren, Molecules, 2016, 21, 901. DOI:10.3390/molecules21070901

2. C. Negro, L. Tommasi, A. Miceli, Bioresour. Technol., 2003, 87, 41-44. DOI:10.1016/S0960-8524(02)00202-X

3. P. Thangaraj, in Pharmacological Assays of Plant-Based Natural Products, Springer, Cham, Switzerland, 2016, pp. 11-13. DOI:10.1007/978-3-319-26811-8_3

4. Altemimi, N. Lakhssassi, A. Baharlouei, D. Watson, D. Lightfoot, Plants, 2017, 6, 42. DOI:10.3390/plants6040042

5. W. I. Haminiuk, G. M. Maciel, M. S. V. Plata-Oviedo and R. M. Peralta, Int. J. Food Sci. Technol., 2012, 47, 2023-2044. DOI:10.1111/j.1365-2621.2012.03067.x

6. M. Hojnik, M. Škerget, Ž. Knez, LWT-Food Sci. Technol., 2008, 41, 2008-2016. DOI:10.1016/j.lwt.2007.11.017

7. M. Boukroufa, C. Boutekedjiret, L. Petigny, N. Rakotomanomana, F. Chemat, Ultrason. Sonochem., 2015, 24, 72-79. DOI:10.1016/j.ultsonch.2014.11.015

8. F. J. Barba, N. Grimi, E. Vorobiev, Food Eng. Rev., 2015, 7, 45-62. DOI:10.1007/s12393-014-9095-6

9. Khoddami, M. A. Wilkes, T. H. Roberts, Molecules, 2013, 18, 2328-2375. DOI:10.3390/molecules 18022328

10. V. Camel, Analyst, 2001, 126, 1182-1193. DOI:10.1039/b008243k

11. F. Chemat, M. A. Vian and G. Cravotto, Int. J. Mol. Sci., 2012, 13, 8615-8627. DOI:10.3390/ijms13078615

12. M. E. Wagner, J. French, S. S. H. Rizvi, J. Food Eng., 2013, 118, 100-107. DOI:10.1016/j.jfoodeng.2013.03.023

13. M. M. R. de Melo, A. J. D. Silvestre, C. M. Silva, J. Supercrit. Fluids, 2014, 92, 115-176. DOI:10.1016/j.supflu.2014.04.007

14. M. Solana, I. Boschiero, S. Dall'Acqua and A. Bertucco, J. Supercrit. Fluids, 2015, 100, 201-208. DOI:10.1016/j.supflu.2015.02.014

15. Capuzzo, M. E. Maffei, A. Occhipinti, Molecules, 2013, 18, 7194-7238. DOI:10.3390/molecules 18067194

16. M. Pinelo, A. Ruiz-Rodríguez, J. Sineiro, F. J. Señoráns, G. Reglero, M. J. Núñez, Eur. Food Res. Technol., 2007, 226, 199205. DOI:10.1007/s00217-006-0526-3

17. W. Huang, Z. Li, H. Niu, D. Li, J. Zhang, J. Food Eng., 2008, 
89, 298-302. DOI:10.1016/j.jfoodeng.2008.05.006

18. S. Stavroulias, C. Panayiotou, Chem. Biochem. Eng. Q., 2005, 19, 373-381.

19. Ł. Woźniak, K. Marszałek, S. Skąpska, Sep. Sci. Technol., 2016, $51,1472-1479$.

20. P. Kraujalis, V. Kraujalienė, R. Kazernavičiūtè, P. R. Venskutonis, J. Supercrit. Fluids, 2017, 122, 99-108.

DOI:10.1016/j.supflu.2016.12.008

21. E. Zondervan, M. Monsanto and J. Meuldijk, Chem. Eng. Trans., 2015, 5, 61-66.

22. K. S. Duba, A. A. Casazza, H. B. Mohamed, P. Perego, L. Fiori, Food Bioprod. Process., 2015, 94, 29-38.

DOI:10.1016/j.fbp.2015.01.001

23. M. Latoui, B. Aliakbarian, A. A. Casazza, M. Seffen, A. Converti, P. Perego, Food Bioprod. Process., 2012, 90, 748-754. DOI:10.1016/j.fbp.2012.01.003

24. A. Casazza, B. Aliakbarian, S. Mantegna, G. Cravotto, P. Perego, J. Food Eng., 2010, 100, 50-55.

DOI:10.1016/j.jfoodeng.2010.03.026

25. Z. Zeković, B. Pavlić, A. Cvetanović, S. Đurović, Ind. Crops Prod., 2016, 94, 353-362.

DOI:10.1016/j.indcrop.2016.09.008

26. K. Aladić, K. Jarni, T. Barbir, S. Vidović, J. Vladić, M. Bilić, S. Jokić, Ind. Crops Prod., 2015, 76, 472-478.

DOI:10.1016/j.indcrop.2015.07.016

27. C. Da Porto, A. Natolino, D. Decorti, LWT - Food Sci. Technol., 2015, 61, 98-104. DOI:10.1016/j.lwt.2014.11.027

28. C. Da Porto, D. Decorti, A. Natolino, J. Supercrit. Fluids, 2016, 107, 38-43. DOI:10.1016/j.supflu.2015.08.006

29. M. S. Lenucci, M. De Caroli, P. P. Marrese, A. Iurlaro, L. Rescio, V. Böhm, G. Dalessandro, G. Piro, Food Chem., 2015, 170, 193-202. DOI:10.1016/j.foodchem.2014.08.081
30. H. Kawamura, K. Mishima, T. Sharmin, S. Ito, R. Kawakami, T. Kato, M. Misumi, T. Suetsugu, H. Orii, H. Kawano, K. Irie, K. Sano, K. Mishima, T. Harada, S. Mustofa, F. Hasanah, Y. D. I. Siregar, H. Zahroh, L. S. E. Putri, A. Salim, Ultrason. Sonochem., 2016, 29, 19-26. DOI:10.1016/j.ultsonch.2015.08.016

31. K. Chhouk, A. T. Quitain, D. G. Pag-asa, J. B. Maridable, M. Sasaki, Y. Shimoyama, M. Goto, J. Supercrit. Fluids, 2016, 110, 167-175. DOI:10.1016/j.supflu.2015.11.016

32. N. Ćujić, K. Šavikin, T. Janković, D. Pljevljakušić, G. Zdunić, S. Ibrić, Food Chem., 2016, 194, 135-142.

DOI:10.1016/j.foodchem.2015.08.008

33. K.-Y. Khaw, M.-O. Parat, P. N. Shaw, J. R. Falconer, Molecules, 2017, 22, 1186. DOI:10.3390/molecules22071186

34. J. M. Prado, I. Dalmolin, N. D. D. Carareto, R. C. Basso, A. J. A. Meirelles, J. Vladimir Oliveira, E. A. C. Batista, M. A. A. Meireles, J. Food Eng., 2012, 109, 249-257.

DOI:10.1016/j.jfoodeng.2011.10.007

35. M. Herrero, A. Cifuentes, E. Ibañez, Food Chem., 2006, 98, 136-148. DOI:10.1016/j.foodchem.2005.05.058

36. K. M. Sharif, M. M. Rahman, J. Azmir, A. Mohamed, M. H. A. Jahurul, F. Sahena and I. S. M. Zaidul, J. Food Eng., 2014, 124, 105-116. DOI:10.1016/j.jfoodeng.2013.10.003

37. G. Brusotti, I. Cesari, A. Dentamaro, G. Caccialanza, G. Massolini, J. Pharm. Biomed. Anal., 2014, 87, 218-228. DOI:10.1016/j.jpba.2013.03.007

38. M. Hadolin, M. Škerget, Z. Knez, D. Bauman, Food Chem., 2001, 74, 355-364. DOI:10.1016/S0308-8146(01)00152-2

39. G. K. Jayaprakasha, R. P. Singh, K. K. Sakariah, Food Chem., 2001, 73, 285-290. DOI:10.1016/S0308-8146(00)00298-3

40. L. J. Porter, L. N. Hrstich, B. G. Chan, Phytochemistry, 1985, 25, 223-230. DOI:10.1016/S0031-9422(00)94533-3

41. T. Vatai, M. Škerget, Ž. Knez, J. Food Eng., 2009, 90, 246-254. DOI:10.1016/j.jfoodeng.2008.06.028

\section{Povzetek}

Določali smo vsebnost fenolnih spojin v ekstraktih, pridobljenih iz tropin rdečega in belega grozdja ter lupin šipka (Rosa canina). Ekstrakti so bili pridobljeni s konvencionalnimi tehnikami ekstrakcije $\mathrm{z}$ uporabo organskih topil in ekstrakcijo $\mathrm{z}$ nadkritičnimi tekočinami (SCFs). Proučevali smo učinek topila, vrste ekstrakcije in eksperimentalnih parametrov (čas, tlak, temperatura) na kvaliteto ekstraktov. Kvantitativno je bila ovrednotena vsebnost skupnih fenolnih spojin in proantocianidinov. S tekočinsko kromatografijo z masno spektrofotometrijo je bil določen profil fenolnih sestavin. Vsem ekstraktom je bila izmerjena antioksidativna učinkovitost. Rezultati kažejo, da je vsebnost posamičnih fenolnih spojin $\mathrm{v}$ ekstraktih, pridobljenih iz različnih vrst materialov, znatno variirala. Najvišja vsebnost skupnih fenolov je bila določena $\mathrm{v}$ ekstraktih iz tropin belega grozdja, pridobljenih z maceriranjem z MeOH (26,7 mg GA / g ekstrakta). Podobna vsebnost, 25,6 mg GA / g ekstrakta, je bila določena v ekstraktu, pridobljenem s Soxhletovo ekstrakcijo z MeOH. Elagna kislina (0,650 mg / 100 g ekstrakta), katehin $(0,164 \mathrm{mg} / 100 \mathrm{~g}$ ekstrakta), galna kislina (0,133 mg / $100 \mathrm{~g}$ ekstrakta) ter kofeinska kislina (0,038 mg / 100 g ekstrakta) da so ekstrakti spojine, ki so v višjem deležu prisotne v maceriranem ekstraktu šipkove lupine; kot topilo je bil uporabljen $\mathrm{MeOH}$. Potrjena je bila tudi prisotnost epitehina, hesperidina / neohepersidina, rutina in klorogenske kisline. Ugotovili smo, da ekstrakti iz naravnih materialov bogat vir fenolnih spojin, njihova vsebnost pa je odvisna od izbire ekstrakcijskega postopka glede na vrsto materiala, vrste topila in obratovalnih pogojev.

Except when otherwise noted, articles in this journal are published under the terms and conditions of the Creative Commons Attribution 4.0 International License 